\title{
Influence of relative abundance of isotopes on depth resolution for depth profiling of metal coatings by laser ablation inductively coupled plasma mass spectrometry
}

\author{
Juan C. Fariñas ${ }^{\mathrm{a}, *}$, Aurora G. Coedo ${ }^{\mathrm{b}}$, Teresa Dorado ${ }^{\mathrm{b}}$ \\ a Instituto de Cerámica y Vidrio (CSIC), Campus de Cantoblanco, Calle Kelsen 5, 28049 Madrid, Spain \\ b Centro Nacional de Investigaciones Metalúrgicas (CSIC), 28040 Madrid, Spain
}

\section{A R T I C L E I N F O}

\section{Article history:}

Received 28 May 2009

Received in revised form

13 November 2009

Accepted 29 November 2009

Available online 16 December 2009

\section{Keywords:}

Metal coatings

Depth profiling

Depth resolution

LA-ICP-MS

\begin{abstract}
A B S T R A C T
A systematic study on the influence of relative abundance of isotopes of elements in the coating $\left(A_{\mathrm{c}}\right)$ and in the substrate $\left(A_{s}\right)$ on both shape of time-resolved signals and depth resolution $(\Delta z)$ was performed for depth profile analysis of metal coatings on metal substrates by ultraviolet $(266 \mathrm{~nm}$ ) nanosecond laser ablation inductively coupled plasma quadrupole mass spectrometry. Five coated samples with coating thicknesses of the same order of magnitude $(20-30 \mu \mathrm{m})$ were tested: nickel coating on aluminium, chromium and copper, and steel coated with copper and zinc. A laser repetition rate of $1 \mathrm{~Hz}$ and a laser fluence of $21 \mathrm{~J} \mathrm{~cm}^{-2}$ were used. Five different depth profile types were established, which showed a clear dependence on $A_{c} / A_{s}$ ratio. In general, depth profiles obtained for ratios above 1-10 could not be used to determine $\Delta z$. We found that $\Delta z$ increased non-linearly with $A_{c} / A_{s}$ ratio. The best depth profile types, leading to highest depth resolution and reproducibility, were attained in all cases by using the isotopes with low/medium $A_{\mathrm{c}}$ values and with the highest $A_{\mathrm{s}}$ values. In these conditions, an improvement of up to 4 times in $\Delta z$ values was achieved. The average ablation rates were in the range from $0.55 \mu \mathrm{m}$ pulse ${ }^{-1}$ for copper coating on steel to $0.83 \mu \mathrm{m}$ pulse ${ }^{-1}$ for zinc coating on steel, and the $\Delta z$ values were between $2.74 \mu \mathrm{m}$ for nickel coating on chromium and $5.91 \mu \mathrm{m}$ for nickel coating on copper, with RSD values about $5-8 \%$.
\end{abstract}

(c) 2009 Elsevier B.V. All rights reserved.

\section{Introduction}

Coated materials have received increasing attention because of their ability to satisfy critical needs that are not fulfilled by any homogeneous material. Single layer or multilayer coatings of different composition and thickness are widely used in the production of high technology materials with enhanced electrical, catalytic, optical, thermal and/or mechanical properties. These properties strongly depend on coating composition (stoichiometry), purity of the materials, thickness, interface between different layers and depth distribution of the coating elements. Therefore, appropriate techniques for surface and depth profile analysis in the $n m-\mu m$ range are required to improve the production technology of such advanced materials.

Laser ablation inductively coupled plasma mass spectrometry (LA-ICP-MS) [1-5] has been applied successfully to the depth profiling analysis of different multilayer and coating samples. Compared with usual techniques suitable for determining the element com-

\footnotetext{
* Corresponding author. Tel.: +34 917355840; fax: +34 917355843.

E-mail address: jcfarinas@icv.csic.es (J.C. Fariñas).
}

position of layered materials as a function of depth (e.g., Auger electron spectroscopy, secondary ion/neutral mass spectrometry, electron probe microanalysis, X-ray photoelectron spectroscopy, dc- or rf- glow discharge optical emission or mass spectrometry, etc.), LA-ICP-MS has numerous advantages: non-vacuum conditions are used; no sample preparation is needed; conducting and non-conducting samples can be analysed; few restrictions concerning shape and dimension of the sample exist; high spatial resolution can be obtained $(0.1-10 \mu \mathrm{m}$ depth and $10-100 \mu \mathrm{m}$ lateral); only a very small quantity of material is ablated; and a rapid, simultaneous, and multielement analysis is feasible at very low detection limits (in the order of $10^{-1}-10^{3} \mathrm{ng} \mathrm{g}^{-1}$ ). Typically, $\mathrm{Nd}$ :YAG or excimer lasers with pulse durations of a few nanoseconds and Ti:sapphire lasers with pulse lengths of about $120 \mathrm{fs}$ have been widely employed for depth profiling analysis by using LA-ICPMS.

Nanosecond LA-ICP-MS has been applied to depth profiling analysis of different kinds of coated samples: compositionally graded Co and Mn perovskite layers [6], steel and WC/Co substrates coated with single layers of $\mathrm{TiC}, \mathrm{TiN}, \mathrm{Ti}(\mathrm{C}, \mathrm{N})$ and $(\mathrm{Ti}, \mathrm{Al}) \mathrm{N}$ [7-9], steel coated with single layers of ZrN, TiN and ZrTiN [10], "composites" formed from two thin wafers of zircon standards 
[11], homogeneous silica-based glass samples and multilayered glass and metal materials [12,13], zinc coated iron sheets [14], copper coatings on steel $[15,16]$, silicon single crystals grown upon a metallic substrate [17], metallurgical-grade silicon of polycrystalline structure [18], multilayered industrial materials [19], multilayered automotive paints [20,21], and ion-selective membranes used in ion-selective electrodes [22]. Coatings with a high range of thicknesses (from 1 to $200 \mu \mathrm{m}$ ) were tested, and the depth resolution obtained was about 2-7 times lower than the corresponding thickness value. In general, ablation rates were 0.1-0.2 $\mu \mathrm{m}$ pulse $^{-1}$ for ceramic layers (perovskites, TiC, TiN, $\mathrm{ZrN}$, and $\mathrm{SiC}$ ) [6-10,19], 0.5-1.0 $\mu \mathrm{m}$ pulse $\mathrm{e}^{-1}$ for metallic coatings ( $\mathrm{Al}, \mathrm{Cu}$, $\mathrm{Si}$, and $\mathrm{Zn}$ ) $[14-16,18,19]$, and $0.5-0.7 \mu \mathrm{mpulse}^{-1}$ for automotive paints $[20,21]$. Some approaches have been evaluated to improve the depth profiling analysis and the depth resolution, as the use of a multi-collector mass spectrometer [11] and an in-house-built Mattauch-Herzog geometry mass spectrograph fitted with a novel array detector (termed the focal plane camera) [15].

Femtosecond LA-ICP-MS has recently been used for the depth profiling analysis of a few layered samples: a single $\mathrm{Cr}$ thin layer on a Ni substrate [23], a complex multilayer polymer coating over a hot-dip galvanized steel substrate [24], and an Al-Zn multilayer structure and a Mg-Zn coating on a steel substrate [25]. The thickness of layers analysed was in the range of $0.5-22 \mu \mathrm{m}$, and the depth resolution obtained was up to 13 times lower than the corresponding thickness value, i.e., better than for ns LA-ICP-MS. In general, ablation rates were of tens of nm pulse ${ }^{-1}$. The usefulness of femtosecond LA-ICP-MS for depth profiling analysis has been improved by modifying the fs Gaussian beam to a flat-top beam [24], and by using a new ablation cell design which enables the mass spectrometer to distinguish material ablated with single laser pulses up to a repetition rate of $20 \mathrm{~Hz}$ [25]. Hergenröder et al. [26] and Fernández et al. [27] have reviewed the main differences between the ablation mechanisms of short ( $>1 \mathrm{ps})$ and ultra-short $(<1 \mathrm{ps})$ laser pulses based on fundamental understanding of the ablation process and the most relevant parameters governing the quality of analysis, have showed the state of the art in fs-LA-ICP-MS, and have presented a variety of examples for depth profiling analysis of multilayer samples. In a recent review, Pisonero and Günther [28] have highlighted the enhanced capabilities of the technique for direct solid sampling, and have discussed about current methods used for quantitative analysis and depth profiling, the ablation process of UV-ns and UV-fs, the influence of the laser beam profile, aerosol structure and transport efficiency, as well as the influence of the ICP-MS (e.g., vaporization and ionization efficiency in the plasma, and type of mass analyzer). More recently, Fernández et al. [29] have briefly reviewed the applications of fs lasers to depth profile analysis at the nanoscale.

The key parameter to evaluate the quality of the in-depth analysis is the depth resolution $(\Delta z)$, which measures the degree of accuracy with which a sharp interface can be described. Depth resolution is defined by convention as the depth interval (i.e., the interface width) where the signal of the measured profile drops from $84 \%$ to $16 \%$ of the maximum signal. The procedure for the determination of $\Delta z$, typically from the depth profile plot of normalized signals, has been explained by Mateo et al. [30]. This procedure has been used by a number of authors [14,16,24]. Another way to determine $\Delta z$ is by means of the maximum slope of the tangent to the transient signal within the coating/substrate interface region. The process is usually performed from the depth profile plot of raw signals, and has been explained by Plotnikov et al. [7]. This method has been utilized in some papers $[7,8,10,14,23]$.

The depth resolution depends on a number of different phenomena that can be categorized into sample characteristics, laser/sample interactions and ICP-MS instrumental factors. Many publications have been devoted to studying the influence of coated
Table 1

LA-ICP-MS operating conditions.

\begin{tabular}{|c|c|}
\hline Parameter & Value \\
\hline \multicolumn{2}{|l|}{ LA (CETAC, LSX-100) } \\
\hline Laser type & Nd:YAG pulsed \\
\hline Laser mode & Q-switched \\
\hline Beam profile & $>95 \%$ fit to Gaussian \\
\hline Beam diameter & $1.0 \mathrm{~mm}$ \\
\hline Wavelength & $266 \mathrm{~nm}$ (ultraviolet) \\
\hline Pulse width & $8 \mathrm{~ns}$ \\
\hline Transverse mode & TEM $_{00}$ single mode \\
\hline Pulse energy output & $2 \mathrm{~mJ}$ \\
\hline Focalization & $\begin{array}{l}\text { Laser beam focused } 2250 \mu \mathrm{m} \\
\text { within sample }\end{array}$ \\
\hline Pulse repetition rate & $1 \mathrm{~Hz}$ \\
\hline Method & Fixed point \\
\hline Ablation cell volume & $100 \mathrm{~cm}^{3}$ \\
\hline $\begin{array}{l}\text { Carrier gas and flow rate into } \\
\text { the ablation cell }\end{array}$ & Argon, $0.651 \mathrm{~min}^{-1}$ \\
\hline $\begin{array}{l}\text { Transport from ablation cell to } \\
\text { MS }\end{array}$ & $\begin{array}{l}\text { Tygon tube ( } 50 \mathrm{~cm} \text { in length, } \\
5 \mathrm{~mm} \text { id) }\end{array}$ \\
\hline \multicolumn{2}{|c|}{ ICP-MS (PERKINELMER SCIEX, ELAN 6000) } \\
\hline Rf forward power & $1200 \mathrm{~W}$ \\
\hline Ar plasma flow rate & $141 \min ^{-1}$ \\
\hline Ar carrier flow rate & $0.65 \mathrm{lmin}^{-1}$ \\
\hline ICP frequency & $40.86 \mathrm{MHz}$ (free-running) \\
\hline Detector & Dual mode \\
\hline Dwell time & $10 \mathrm{~ms}$ \\
\hline Sweeps/reading & 4 \\
\hline Estimated reading time & $1.092 \mathrm{~s}$ \\
\hline Readings/replicate & $\begin{array}{l}\text { As many as provide enough } \\
\text { replicate time to reach the } \\
\text { substrate }\end{array}$ \\
\hline Replicates & 1 \\
\hline
\end{tabular}

(or multilayered) sample type (mainly oxidic ceramics [6], nonoxide-based ceramics [7-10], glasses [13], metals [13-16,23] and polymers [24]) and coating thickness $[7,9,13,16]$ on $\Delta z$. Most of the work carried out so far has been focused on the study of the dependence of depth resolution (and/or depth profile shape) on different laser parameters: wavelength [13,14], energy distribution profile of laser beam [13,14], volume and/or shape of ablation cell [8-10], carrier gas into the ablation cell [13], laser pulse energy (or laser irradiance) $[7,9,13,14,16,19]$, pulse repetition rate $[7,9]$, spot size $[7,10,11,14]$ and crater depth/diameter ratio (or crater geometry) $[13,19]$. However, to the best of our knowledge, reports on the variation of $\Delta z$ with ICP-MS measurement conditions have not been published.

The aim of the present work was to systematically study the influence of relative abundance of isotopes of elements in the coating and in the substrate on both shape of time-resolved signals and depth resolution for depth profile analysis of metal coatings on metal substrates by ultraviolet nanosecond LA-ICP-MS, using coated samples with coating thicknesses of the same order of magnitude.

\section{Experimental}

\subsection{Instrumentation}

Experiments were performed with a commercially available quadrupled $(266 \mathrm{~nm})$ nanosecond Nd:YAG laser with Q-switch (LSX-100, CETAC Technologies, Omaha, NB, USA) coupled to an ICP quadrupole mass spectrometer (ELAN 6000, PerkinElmer SCIEX, Thornhill, Ontario, Canada). The operating conditions of both the laser ablation and the ICP-MS instruments are listed in Table 1. The analytes and their isotopic compositions are shown in Table 2. Vaporization enthalpy and thermal conductivity values of the analytes are also included in Table 2. All the isotopes for each element were tested. The CCD camera microscope viewing system 
Table 2

Analytes, thermal properties and isotopic compositions.

\begin{tabular}{|c|c|c|c|c|}
\hline Element & Vaporization enthalpy $\left(\mathrm{kJ} \mathrm{mol}^{-1}\right)$ & Thermal conductivity $\left(\mathrm{W} \mathrm{m}^{-1} \mathrm{~K}^{-1}\right.$ ) & Isotope & Relative abundance (\%) \\
\hline $\mathrm{Al}$ & 293.4 & 237 & ${ }^{27} \mathrm{Al}$ & 100 \\
\hline $\mathrm{Cr}$ & 344.3 & 94 & $\begin{array}{l}{ }^{52} \mathrm{Cr} \\
{ }^{53} \mathrm{Cr} \\
{ }^{50} \mathrm{Cr} \\
{ }^{54} \mathrm{Cr}\end{array}$ & $\begin{array}{r}83.789 \\
9.501 \\
4.345 \\
2.365\end{array}$ \\
\hline $\mathrm{Cu}$ & 300.3 & 401 & $\begin{array}{l}{ }^{63} \mathrm{Cu} \\
{ }^{65} \mathrm{Cu}\end{array}$ & $\begin{array}{l}69.17 \\
30.83\end{array}$ \\
\hline $\mathrm{Fe}$ & 349.6 & 80.2 & $\begin{array}{l}{ }^{56} \mathrm{Fe} \\
{ }^{54} \mathrm{Fe} \\
{ }^{57} \mathrm{Fe} \\
{ }^{58} \mathrm{Fe}\end{array}$ & $\begin{array}{c}91.72 \\
5.8 \\
2.2 \\
0.28\end{array}$ \\
\hline $\mathrm{Ni}$ & 370.4 & 90.7 & $\begin{array}{l}{ }^{58} \mathrm{Ni} \\
{ }^{60} \mathrm{Ni} \\
{ }^{62} \mathrm{Ni} \\
{ }^{61} \mathrm{Ni} \\
{ }^{64} \mathrm{Ni}\end{array}$ & $\begin{array}{r}68.077 \\
26.223 \\
3.634 \\
1.140 \\
0.926\end{array}$ \\
\hline $\mathrm{Zn}$ & 115.3 & 116 & $\begin{array}{l}{ }^{64} \mathrm{Zn} \\
{ }^{66} \mathrm{Zn} \\
{ }^{68} \mathrm{Zn} \\
{ }^{67} \mathrm{Zn} \\
{ }^{70} \mathrm{Zn}\end{array}$ & $\begin{array}{r}48.6 \\
27.9 \\
18.8 \\
4.1 \\
0.6\end{array}$ \\
\hline
\end{tabular}

provides a means of visual laser focusing. Instrument conditions were optimized for best time-resolved data acquisition. All ICP-MS data were collected in peak hopping mode and one point per peak, using transient signal data acquisition and time-resolved software. The laser pulse energy was measured with a laser power/energy meter (EM 400, Molectron Detector, Inc., USA). The diameter of the craters was measured by optical microscopy, and their morphology was observed by scanning electron microscopy, (DSM 400, Zeiss, Germany).

\subsection{Samples}

Five coated samples were tested: nickel coating on aluminium $(\mathrm{Ni} / \mathrm{Al})$, chromium $(\mathrm{Ni} / \mathrm{Cr})$ and copper $(\mathrm{Ni} / \mathrm{Cu})$, and steel coated with copper $(\mathrm{Cu} / \mathrm{Fe})$ and zinc $(\mathrm{Zn} / \mathrm{Fe})$. The coating thicknesses and uncertainties were $29.9 \pm 0.2,20.4 \pm 0.4,25.1 \pm 0.4,25.3 \pm 0.4$ and $22.3 \pm 0.3 \mu \mathrm{m}$, respectively. The $\mathrm{Cu} / \mathrm{Fe}$ sample is the standard reference material 1361b (certified for total coating thickness) from NIST (National Institute of Standards and Technology). The sample consists of an American Iron and Steel Institute (AISI) 1010 cold rolled sheet steel substrate with a uniform coating of copper. The other four samples were prepared at the Spanish National Centre for Metallurgical Research (CSIC). Pure ( $\geq 99.999 \%) \mathrm{Al}, \mathrm{Cr}$ and $\mathrm{Cu}$ sheets were coated with electrochemically-deposited Ni plating, and steel sheet with electrochemically-deposited Zn (galvanized) plating. Coating thicknesses were controlled during the electrolytic process, and later characterized, by glow discharge optical emission spectrometry (LECO SA-2000 surface analyzer instrument, USA). To calibrate the instrument, both pure metals and binary alloys with known sputtering rate were used. Prior to analysis, the samples were cleaned with methanol, rinsed with deionized water and dried.

\subsection{Procedure}

The depth characterization of the single layer samples was performed by continuously and simultaneously monitoring, as a function of number of laser pulses, the ion intensities of all the different isotopes of the elements (Table 2 ) in both the coating and the substrate from multiple laser pulses fired at a fixed location. The individual pulse raw signals were corrected from an average of the background signal at the mass number of the measured analyte (when no analyte is present). Table 3 summarizes all the pairs of isotopes used to perform the depth profiles ( 5 pairs for $\mathrm{Ni} / \mathrm{Al}$ sample, 20 for $\mathrm{Ni} / \mathrm{Cr}$ sample, 10 for $\mathrm{Ni} / \mathrm{Cu}$ sample, 8 for $\mathrm{Cu} / \mathrm{Fe}$ sample, and 20 for $\mathrm{Zn} / \mathrm{Fe}$ sample), as well as, for each pair of isotopes, the relative abundance of the isotope of the element in the coating $\left(A_{\mathrm{c}}\right)$, the relative abundance of the isotope of the element in the substrate $\left(A_{\mathrm{S}}\right)$, and $A_{\mathrm{C}} / A_{\mathrm{S}}$ ratio. Depth profile type obtained for each pair of isotopes (see further, under Section 3 ) is also included in Table 3.

The procedure followed for the determination of $\Delta z$ was explained elsewhere [16,30]. The $\Delta z$ values were calculated for each pair of isotopes (summarized in Table 3 ) from the depth profile plots of normalized signals $(N)$ against number of laser pulses. The normalized signals are the ratio between the raw ion intensity of an isotope and the addition of the raw ion intensity of that isotope plus the raw ion intensity of the other isotope. For example, for the depth profile of $\mathrm{Zn} / \mathrm{Fe}$ sample by using ${ }^{64} \mathrm{Zn}$ and ${ }^{56} \mathrm{Fe}$ isotopes (abbreviated as ${ }^{64} \mathrm{Zn}-{ }^{56} \mathrm{Fe}$ in Table 3 ), normalized signal for ${ }^{64} \mathrm{Zn}$ $\left(N_{\mathrm{Zn}}\right)$ is equal to $I_{\mathrm{Zn}}\left(I_{\mathrm{Zn}}+I_{\mathrm{Fe}}\right)^{-1}$ and normalized signal for ${ }^{56} \mathrm{Fe}\left(N_{\mathrm{Fe}}\right)$ is equal to $I_{\mathrm{Fe}}\left(I_{\mathrm{Zn}}+I_{\mathrm{Fe}}\right)^{-1}$, being $I_{\mathrm{Zn}}$ and $I_{\mathrm{Fe}}$ the raw ion intensities of ${ }^{64} \mathrm{Zn}$ and ${ }^{56} \mathrm{Fe}$, respectively. The following equation was applied for determining $\Delta z$ :

$\Delta z(\mu \mathrm{m})=\Delta P($ pulses $) \operatorname{AAR}\left(\mu \mathrm{m}\right.$ pulse $\left.^{-1}\right)$

where $\Delta P$ is the difference in the number of laser pulses necessary to reach $84 \%\left(P_{84}\right)$ and $16 \%\left(P_{16}\right)$ of the normalized signal intensity (i.e., $\left.\Delta P=P_{16}-P_{84}\right)$, and AAR is the average ablation rate, which is obtained by dividing the thickness of the coating $(D)$ by the number of pulses required to reach the coating/substrate interface $\left(P_{50}\right)$, being $P_{50}$ the number of laser pulses corresponding to a value of normalized intensity 0.50 (i.e., $50 \%$ of the full signal).

The error bars in the plots represent standard deviation values based on 5 replicates.

\section{Results and discussion}

In a previous paper [16], we have studied the influence of irradiance on depth resolution for depth profile analysis of copper coating on steel. Irradiance, that is the only factor influencing this figure of merit for a particular LA system, sample and ICP-MS operating 
Table 3

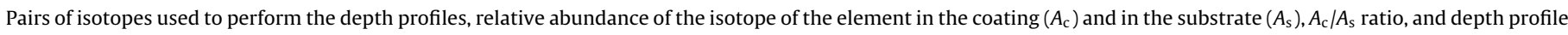
type obtained for each pair of isotopes.

\begin{tabular}{|c|c|c|c|c|c|c|c|c|c|c|c|}
\hline Sample & Pair of isotopes & $A_{\mathrm{c}}(\%)$ & $A_{\mathrm{s}}(\%)$ & $A_{\mathrm{c}} / A_{\mathrm{s}}$ & $\begin{array}{l}\text { Depth } \\
\text { profile type }\end{array}$ & Sample & Pair of isotopes & $A_{\mathrm{c}}(\%)$ & $A_{\mathrm{s}}(\%)$ & $A_{\mathrm{c}} / A_{\mathrm{s}}$ & $\begin{array}{l}\text { Depth } \\
\text { profile type }\end{array}$ \\
\hline \multirow[t]{5}{*}{$\mathrm{Ni} / \mathrm{Al}$} & ${ }^{58} \mathrm{Ni}-{ }^{27} \mathrm{Al}$ & 68.077 & 100 & 0.681 & III & \multirow[t]{8}{*}{$\mathrm{Cu} / \mathrm{Fe}$} & ${ }^{63} \mathrm{Cu}-{ }^{56} \mathrm{Fe}$ & 69.170 & 91.720 & 0.754 & IV \\
\hline & ${ }^{60} \mathrm{Ni}-{ }^{27} \mathrm{Al}$ & 26.223 & 100 & 0.262 & IV & & ${ }^{63} \mathrm{Cu}-{ }^{54} \mathrm{Fe}$ & 69.170 & 5.800 & 11.926 & I \\
\hline & ${ }^{62} \mathrm{Ni}-{ }^{27} \mathrm{Al}$ & 3.634 & 100 & 0.036 & V & & ${ }^{63} \mathrm{Cu}-{ }^{57} \mathrm{Fe}$ & 69.170 & 2.200 & 31.441 & I \\
\hline & ${ }^{61} \mathrm{Ni}-{ }^{27} \mathrm{Al}$ & 1.140 & 100 & 0.011 & V & & ${ }^{63} \mathrm{Cu}-{ }^{58} \mathrm{Fe}$ & 69.170 & 0.280 & 247.036 & I \\
\hline & ${ }^{64} \mathrm{Ni}-{ }^{27} \mathrm{Al}$ & 0.926 & 100 & 0.009 & V & & ${ }^{65} \mathrm{Cu}-{ }^{56} \mathrm{Fe}$ & 30.830 & 91.720 & 0.336 & IV \\
\hline \multirow[t]{20}{*}{$\mathrm{Ni} / \mathrm{Cr}$} & ${ }^{58} \mathrm{Ni}-{ }^{52} \mathrm{Cr}$ & 68.077 & 83.789 & 0.812 & IV & & ${ }^{65} \mathrm{Cu}-{ }^{54} \mathrm{Fe}$ & 30.830 & 5.800 & 5.316 & I \\
\hline & ${ }^{58} \mathrm{Ni}-{ }^{53} \mathrm{Cr}$ & 68.077 & 9.501 & 7.165 & II & & ${ }^{65} \mathrm{Cu}-{ }^{57} \mathrm{Fe}$ & 30.830 & 2.200 & 14.014 & I \\
\hline & ${ }^{58} \mathrm{Ni}-{ }^{50} \mathrm{Cr}$ & 68.077 & 4.345 & 15.668 & I & & ${ }^{65} \mathrm{Cu}-{ }^{58} \mathrm{Fe}$ & 30.830 & 0.280 & 110.107 & I \\
\hline & ${ }^{58} \mathrm{Ni}-{ }^{54} \mathrm{Cr}$ & 68.077 & 2.365 & 28.785 & I & \multirow[t]{27}{*}{$\mathrm{Zn} / \mathrm{Fe}$} & ${ }^{64} \mathrm{Zn}-{ }^{56} \mathrm{Fe}$ & 48.600 & 91.720 & 0.530 & IV \\
\hline & ${ }^{60} \mathrm{Ni}-{ }^{52} \mathrm{Cr}$ & 26.223 & 83.789 & 0.313 & IV & & ${ }^{64} \mathrm{Zn}-{ }^{54} \mathrm{Fe}$ & 48.600 & 5.800 & 8.379 & III \\
\hline & ${ }^{60} \mathrm{Ni}-{ }^{53} \mathrm{Cr}$ & 26.223 & 9.501 & 2.760 & II & & ${ }^{64} \mathrm{Zn}-{ }^{57} \mathrm{Fe}$ & 48.600 & 2.200 & 22.091 & I \\
\hline & ${ }^{60} \mathrm{Ni}-{ }^{50} \mathrm{Cr}$ & 26.223 & 4.345 & 6.035 & I & & ${ }^{64} \mathrm{Zn}-{ }^{58} \mathrm{Fe}$ & 48.600 & 0.280 & 173.571 & I \\
\hline & ${ }^{60} \mathrm{Ni}-{ }^{54} \mathrm{Cr}$ & 26.223 & 2.365 & 11.088 & I & & ${ }^{66} \mathrm{Zn}-{ }^{56} \mathrm{Fe}$ & 27.900 & 91.720 & 0.304 & IV \\
\hline & ${ }^{62} \mathrm{Ni}-{ }^{52} \mathrm{Cr}$ & 3.634 & 83.789 & 0.043 & V & & ${ }^{66} \mathrm{Zn}-{ }^{54} \mathrm{Fe}$ & 27.900 & 5.800 & 4.810 & III \\
\hline & ${ }^{62} \mathrm{Ni}-{ }^{53} \mathrm{Cr}$ & 3.634 & 9.501 & 0.382 & III & & ${ }^{66} \mathrm{Zn}-{ }^{57} \mathrm{Fe}$ & 27.900 & 2.200 & 12.682 & I \\
\hline & ${ }^{62} \mathrm{Ni}-{ }^{50} \mathrm{Cr}$ & 3.634 & 4.345 & 0.836 & II & & ${ }^{66} \mathrm{Zn}-{ }^{58} \mathrm{Fe}$ & 27.900 & 0.280 & 99.643 & I \\
\hline & ${ }^{62} \mathrm{Ni}-{ }^{54} \mathrm{Cr}$ & 3.634 & 2.365 & 1.537 & II & & ${ }^{68} \mathrm{Zn}-{ }^{56} \mathrm{Fe}$ & 18.800 & 91.720 & 0.205 & IV \\
\hline & ${ }^{61} \mathrm{Ni}-{ }^{52} \mathrm{Cr}$ & 1.140 & 83.789 & 0.014 & V & & ${ }^{68} \mathrm{Zn}-{ }^{54} \mathrm{Fe}$ & 18.800 & 5.800 & 3.241 & III \\
\hline & ${ }^{61} \mathrm{Ni}-{ }^{53} \mathrm{Cr}$ & 1.140 & 9.501 & 0.120 & IV & & ${ }^{68} \mathrm{Zn}-{ }^{57} \mathrm{Fe}$ & 18.800 & 2.200 & 8.545 & II \\
\hline & ${ }^{61} \mathrm{Ni}-{ }^{50} \mathrm{Cr}$ & 1.140 & 4.345 & 0.262 & III & & ${ }^{68} \mathrm{Zn}-{ }^{58} \mathrm{Fe}$ & 18.800 & 0.280 & 67.143 & I \\
\hline & ${ }^{61} \mathrm{Ni}-{ }^{54} \mathrm{Cr}$ & 1.140 & 2.365 & 0.482 & III & & ${ }^{67} \mathrm{Zn}-{ }^{56} \mathrm{Fe}$ & 4.100 & 91.720 & 0.045 & V \\
\hline & ${ }^{64} \mathrm{Ni}-{ }^{52} \mathrm{Cr}$ & 0.926 & 83.789 & 0.011 & V & & ${ }^{67} \mathrm{Zn}-{ }^{54} \mathrm{Fe}$ & 4.100 & 5.800 & 0.707 & IV \\
\hline & ${ }^{64} \mathrm{Ni}-{ }^{53} \mathrm{Cr}$ & 0.926 & 9.501 & 0.097 & III & & ${ }^{67} \mathrm{Zn}-{ }^{57} \mathrm{Fe}$ & 4.100 & 2.200 & 1.864 & III \\
\hline & ${ }^{64} \mathrm{Ni}-{ }^{50} \mathrm{Cr}$ & 0.926 & 4.345 & 0.213 & III & & ${ }^{67} \mathrm{Zn}-{ }^{58} \mathrm{Fe}$ & 4.100 & 0.280 & 14.643 & I \\
\hline & ${ }^{64} \mathrm{Ni}-{ }^{54} \mathrm{Cr}$ & 0.926 & 2.365 & 0.392 & III & & ${ }^{70} \mathrm{Zn}-{ }^{56} \mathrm{Fe}$ & 0.600 & 91.720 & 0.007 & V \\
\hline \multirow[t]{10}{*}{$\mathrm{Ni} / \mathrm{Cu}$} & ${ }^{58} \mathrm{Ni}-{ }^{63} \mathrm{Cu}$ & 68.077 & 69.170 & 0.984 & IV & & ${ }^{70} \mathrm{Zn}-{ }^{54} \mathrm{Fe}$ & 0.600 & 5.800 & 0.103 & III \\
\hline & ${ }^{58} \mathrm{Ni}-{ }^{65} \mathrm{Cu}$ & 68.077 & 30.830 & 2.208 & IV & & ${ }^{70} \mathrm{Zn}-{ }^{57} \mathrm{Fe}$ & 0.600 & 2.200 & 0.273 & IV \\
\hline & ${ }^{60} \mathrm{Ni}-{ }^{63} \mathrm{Cu}$ & 26.223 & 69.170 & 0.379 & IV & & ${ }^{70} \mathrm{Zn}-{ }^{58} \mathrm{Fe}$ & 0.600 & 0.280 & 2.143 & III \\
\hline & ${ }^{60} \mathrm{Ni}-{ }^{65} \mathrm{Cu}$ & 26.223 & 30.830 & 0.851 & IV & & & & & & \\
\hline & ${ }^{62} \mathrm{Ni}-{ }^{63} \mathrm{Cu}$ & 3.634 & 69.170 & 0.053 & V & & & & & & \\
\hline & ${ }^{62} \mathrm{Ni}-{ }^{65} \mathrm{Cu}$ & 3.634 & 30.830 & 0.118 & V & & & & & & \\
\hline & ${ }^{61} \mathrm{Ni}-{ }^{63} \mathrm{Cu}$ & 1.140 & 69.170 & 0.016 & V & & & & & & \\
\hline & ${ }^{61} \mathrm{Ni}-{ }^{65} \mathrm{Cu}$ & 1.140 & 30.830 & 0.037 & V & & & & & & \\
\hline & ${ }^{64} \mathrm{Ni}-{ }^{63} \mathrm{Cu}$ & 0.926 & 69.170 & 0.013 & V & & & & & & \\
\hline & ${ }^{64} \mathrm{Ni}-{ }^{65} \mathrm{Cu}$ & 0.926 & 30.830 & 0.030 & V & & & & & & \\
\hline
\end{tabular}

conditions, depends only on the laser pulse energy and on the diameter of the crater (which was varied by changing the focalization). It was established that the best depth resolution (i.e., the lowest $\Delta z$ ) was obtained for a laser pulse energy of $2 \mathrm{~mJ}$ and by focusing the laser beam $2250 \mu \mathrm{m}$ within sample. Taking into account the goal of the present work, the laser irradiance applied on the five samples must be the same, for comparative purposes. We have tested several pairs of isotopes for each sample, and we have verified that these conditions provide suitable sensitivities for all the measured isotopes. As a compromise between irradiance and depth resolution, laser pulse energy and defocusing were fixed at $2 \mathrm{~mJ}$ and $2250 \mu \mathrm{m}$, respectively, and these values were used for all further experiments. The craters obtained by using these energy and focusing conditions are very similar for the five samples. These cone-like craters present a typical morphology caused by the predominant thermal effects associated with nanosecond UV pulsed laser ablation of metals (i.e., sample removing in both vapor and liquid phases), with the walls and rim covered with a thin molten film formed through melt expulsion by the high vapor pressure and re-solidified molten material (droplets) at the surface around the crater. The crater diameter attained for the five samples is about $110 \mu \mathrm{m}$. The corresponding laser fluence is $21 \mathrm{~J} \mathrm{~cm}^{-2}$, equivalent to a irradiance of $2.6 \mathrm{GW} \mathrm{cm}^{-2}$. This fluence value is much higher than the threshold laser fluence $\left(F_{\text {th }}\right)$ of the six elements studied, which varies from $0.57 \mathrm{~J} \mathrm{~cm}^{-2}$ for $\mathrm{Zn}$ and $3.28 \mathrm{~J} \mathrm{~cm}^{-2}$ for $\mathrm{Cu}$ (theoretical values) [31]. The depth/diameter ratio of the ablation crater is lower than 1 in all cases. In these conditions, we are ablating well above the ablation threshold of the materials and we are using large ablation craters, as suggested by Mank and Mason [12] for depth analysis.
The 63 normalized depth profiles obtained for the five samples by using the 63 different pairs of isotopes listed in Table 3 can be classified, according with the shape of the normalized signals, into five different depth profile types, termed I to $\mathrm{V}$, which are depicted in Fig. 1. The depth profile type corresponding to each pair of isotopes is summarized in Table 3.

In depth profile type I, crossing of normalized signals does not occur, and $P_{50}$ and $P_{16}$ parameters cannot be determined. This depth profile type is obtained, for $\mathrm{Ni} / \mathrm{Cr}, \mathrm{Cu} / \mathrm{Fe}$ and $\mathrm{Zn} / \mathrm{Fe}$ samples, at $A_{\mathrm{c}} / A_{\mathrm{s}}$ ratios higher than 5, corresponding to the highest values of $A_{\mathrm{c}}$ and the lowest values of $A_{\mathrm{s}}$.

In depth profile type II, crossing of normalized signals occur, but $P_{16}$ parameter cannot be determined. This depth profile type is obtained, for $\mathrm{Ni} / \mathrm{Cr}$ and $\mathrm{Zn} / \mathrm{Fe}$ samples, at $A_{\mathrm{C}} / A_{\mathrm{S}}$ ratios ranging from $\approx 1$ to $\approx 8$, corresponding to high values of $A_{\mathrm{c}}$ and relatively low values of $A_{s}$, although it is also attained for ${ }^{62} \mathrm{Ni}-{ }^{50} \mathrm{Cr}$ and ${ }^{62} \mathrm{Ni}-{ }^{54} \mathrm{Cr}$ pairs of isotopes with low values of $A_{c}$ (3.634\%).

Obviously, depth profile types I and II (21 in total), which are obtained in general by using the highest values of $A_{\mathrm{c}}$ and the lowest values of $A_{\mathrm{s}}$ (leading to the highest $A_{\mathrm{C}} / A_{\mathrm{S}}$ ratios), cannot be used for determination of $\Delta z$. The unsuitable shape of both depth profile types can be due to the high ion signals obtained from the high $A_{\mathrm{c}}$ values and to the low ion signals attained from the low $A_{\mathrm{s}}$ values. When the interface is reached, the coating still continues to be ablated because of the Gaussian shape of the laser beam. Therefore, using a high $A_{\mathrm{c}}$ permits to easily detect the coating (even with a small amount of material ablated) whereas a low $A_{\mathrm{s}}$ makes the detection of the substrate harder.

In depth profile type III, normalized signals present many fluctuations at $0.84,0.50$ and mainly, 0.16 normalized intensity values. 

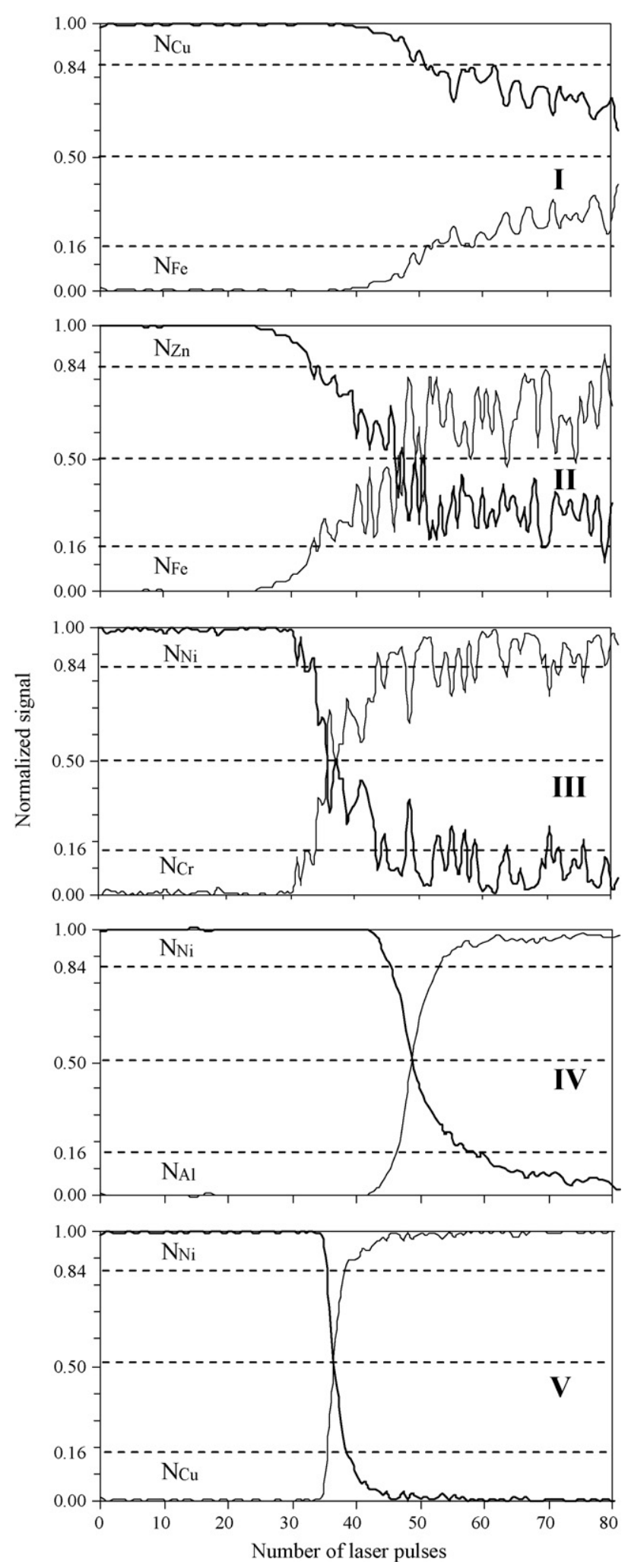

Fig. 1. Five different depth profile types obtained for the five samples by using the 63 different pairs of isotopes listed in Table 3: type $\mathrm{I}\left({ }^{63} \mathrm{Cu}-{ }^{54} \mathrm{Fe}\right.$ pair, $\mathrm{Cu} / \mathrm{Fe}$ sample), type II $\left({ }^{67} \mathrm{Zn}-{ }^{58} \mathrm{Fe}\right.$ pair, $\mathrm{Zn} / \mathrm{Fe}$ sample), type III $\left({ }^{61} \mathrm{Ni}-{ }^{50} \mathrm{Cr}\right.$ pair, $\mathrm{Ni} / \mathrm{Cr}$ sample), type IV ( ${ }^{60} \mathrm{Ni}-{ }^{27} \mathrm{Al}$ pair, $\mathrm{Ni} / \mathrm{Al}$ sample), and type $\mathrm{V}\left({ }^{62} \mathrm{Ni}-{ }^{63} \mathrm{Cu}\right.$ pair, $\mathrm{Ni} / \mathrm{Cu}$ sample $)$.

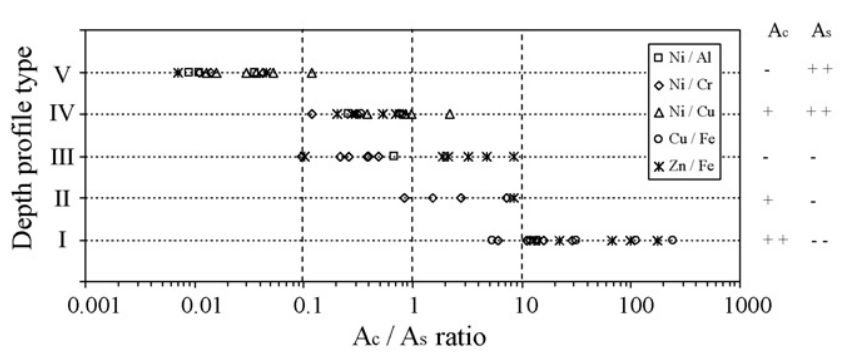

Fig. 2. Dependence of depth profile type on $A_{\mathrm{c}} / A_{\mathrm{s}}$ ratio. Approximate values of $A_{\mathrm{c}}$ and $A_{s}$ (++, very high; +, high; --, very low; -, low) for each depth profile type are included.

These depth profile types are obtained, for $\mathrm{Ni} / \mathrm{Al}, \mathrm{Ni} / \mathrm{Cr}$ and $\mathrm{Zn} / \mathrm{Fe}$ samples, by using low values of both $A_{\mathrm{c}}$ and $A_{\mathrm{s}}$, with $A_{\mathrm{c}} / A_{\mathrm{s}}$ ratios in the range from 0.1 to $\approx 8$, although it is also attained for ${ }^{58} \mathrm{Ni}-{ }^{27} \mathrm{Al}$ and ${ }^{64} \mathrm{Zn}-{ }^{54} \mathrm{Fe}$ pairs of isotopes with the highest values of $A_{\mathrm{c}}$ (68.077\% and $48.600 \%$, respectively).

Depth profile type IV, in which normalized signals do not reach 0 and 1 values after the coating/substrate interface, is obtained for the five samples by using high values of both $A_{\mathrm{c}}$ and $A_{\mathrm{s}}$, with $A_{\mathrm{c}} / A_{\mathrm{s}}$ ratios in the range from 0.1 to 2.2 , although it is also attained for ${ }^{61} \mathrm{Ni}-{ }^{53} \mathrm{Cr},{ }^{67} \mathrm{Zn}-{ }^{54} \mathrm{Fe}$ and ${ }^{70} \mathrm{Zn}-{ }^{57} \mathrm{Fe}$ pairs of isotopes, which present low values of both $A_{\mathrm{c}}$ and $A_{\mathrm{s}}$ values.

Depth profile type $\mathrm{V}$, in which normalized signals reach 0 and 1 values after the coating/substrate interface, is obtained for $\mathrm{Ni} / \mathrm{Al}$, $\mathrm{Ni} / \mathrm{Cr}, \mathrm{Ni} / \mathrm{Cu}$ and $\mathrm{Zn} / \mathrm{Fe}$ samples by using low values of $A_{\mathrm{c}}$ and the highest values of $A_{\mathrm{s}}$, with $A_{\mathrm{c}} / A_{\mathrm{s}}$ ratios lower than 0.1 .

Depth profile types I, II and III are similar to that obtained for $\mathrm{Cu} / \mathrm{Fe}$ sample at poorer irradiance values (lower than $\approx 2 \mathrm{GW} \mathrm{cm}^{-2}$ ) [16], whereas depth profile types IV and $\mathrm{V}$ are analogous to that attained at more appropriate irradiance values (higher than $\approx 2 \mathrm{GW} \mathrm{cm}^{-2}$ ).

The previous results are summarized in Fig. 2, which shows the dependence of depth profile type on $A_{\mathrm{c}} / A_{\mathrm{s}}$ ratio for the five samples. As can be seen, one depth profile type is obtained for each $A_{\mathrm{c}} / A_{\mathrm{s}}$ ratio range. Thus, for $A_{\mathrm{c}} / A_{\mathrm{s}}$ ratios lower than 0.1 , depth profile type $\mathrm{V}$ (corresponding to low $A_{\mathrm{c}}$ values and high $A_{\mathrm{s}}$ values) is achieved. For $A_{\mathrm{c}} / A_{\mathrm{S}}$ ratio in the range from 0.1 to 1 , depth profile type IV (corresponding to high $A_{\mathrm{c}}$ and $A_{\mathrm{s}}$ values) is attained. For $A_{\mathrm{C}} / A_{\mathrm{S}}$ ratio in the range from 1 to 10 , depth profile type II (corresponding to high $A_{\mathrm{c}}$ values and low $A_{\mathrm{s}}$ values) is obtained. For $A_{\mathrm{c}} / A_{\mathrm{s}}$ ratio in the range from 0.1 to 10 , depth profile type III (corresponding to low $A_{\mathrm{c}}$ and $A_{\mathrm{s}}$ values) is achieved. For $A_{\mathrm{c}} / A_{\mathrm{s}}$ ratios higher than 10 , depth profile type I (corresponding to high $A_{\mathrm{c}}$ values and low $A_{\mathrm{S}}$ values) is attained.

The $\Delta z$ values determined by using Eq. (1) for each pair of isotopes listed in Table 3 (excluding obviously those leading to depth profile types I and II) from the corresponding depth profiles are plotted as a function of $A_{\mathrm{C}} / A_{\mathrm{S}}$ ratio for the five samples in Fig. 3, where the depth profile type associated to each point is also included. As can be seen, the general behaviour is similar in all cases: the higher the $A_{\mathrm{c}} / A_{\mathrm{s}}$ ratio, the higher the $\Delta z$ value. For each sample, the higher standard deviation values are obtained for higher $A_{\mathrm{c}} / A_{\mathrm{s}}$ ratio values, mostly for those corresponding to depth profile type III (Fig. 3a, b and e), which can be explained by the fluctuations in normalized signals of such depth profile type (Fig. 1) and, consequently, by the uncertainty in the determination of $P_{84}$, $P_{50}$ and/or $P_{16}$ parameters. The noticeable diminution of $\Delta z$ values (Fig. 3b) corresponding to depth profile type IV at $A_{\mathrm{c}} / A_{\mathrm{s}}$ ratio values of 0.313 and 0.812 with regard to those corresponding to depth profile type III can be attributed to the very low values of both $A_{\mathrm{c}}$ and $A_{\mathrm{s}}$ of the latter. For three nickel-coated samples, as well as for $\mathrm{Zn} / \mathrm{Fe}$ sample, the high standard deviation values associated with lower $\Delta z$ values attained for depth profile type $\mathrm{V}$ at 

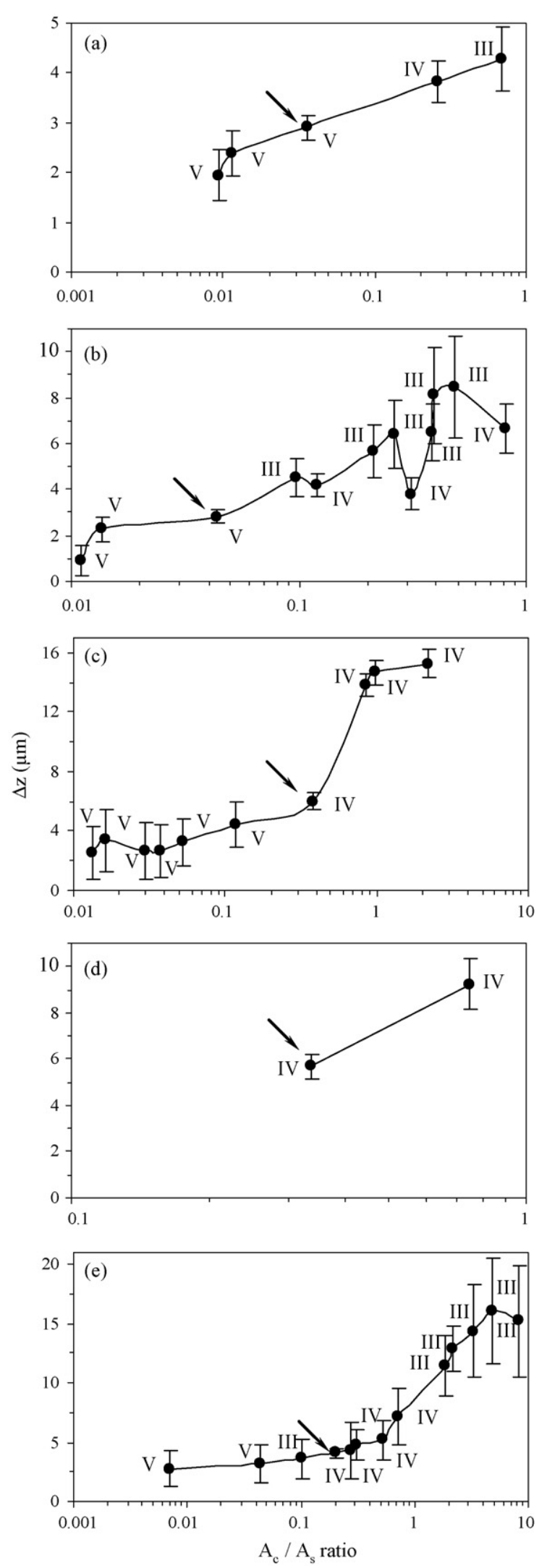

Fig. 3. Dependence of $\Delta z$ on $A_{c} / A_{s}$ ratio for the five samples: $\mathrm{Ni} / \mathrm{Al}$ (a), $\mathrm{Ni} / \mathrm{Cr}$ (b), $\mathrm{Ni} / \mathrm{Cu}(\mathrm{c}), \mathrm{Cu} / \mathrm{Fe}(\mathrm{d})$, and $\mathrm{Zn} / \mathrm{Fe}(\mathrm{e})$. Depth profile type for each point is included. Arrows indicate $\Delta z$ value with lowest standard deviation.

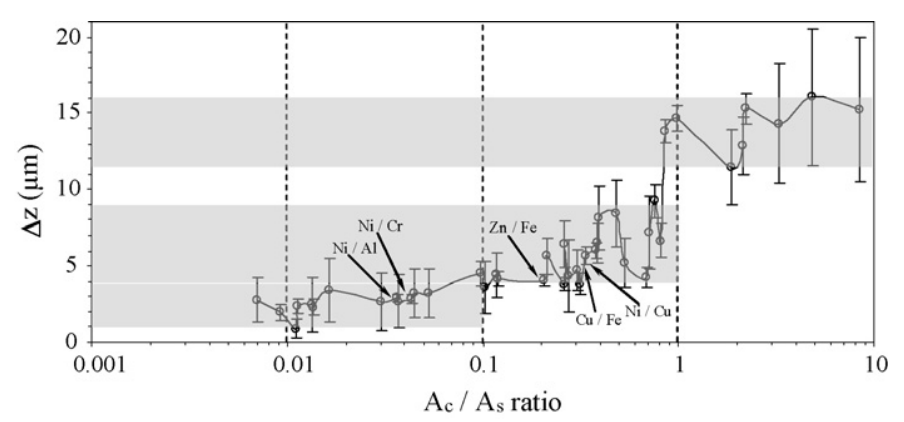

Fig. 4. Overall dependence of $\Delta z$ on $A_{\mathrm{c}} / A_{\mathrm{s}}$ ratio for the five samples. Arrows indicate $\Delta z$ value with lowest standard deviation for each sample.

$A_{\mathrm{c}} / A_{\mathrm{S}}$ ratio values about 0.01 (Fig. 3a and b) and $0.01-0.1$ (Fig. 3c and e) can be related to the very low values of $A_{c}$ (3.634\%, $1.140 \%$ and $0.926 \%$ for $\mathrm{Ni}$ and $4.100 \%$ and $0.600 \%$ for $\mathrm{Zn}$ ), i.e., to the low sensitivity of the isotopes measured in the coating. The $\Delta z$ values obtained are comprised between 1.9 and $4.3 \mu \mathrm{m}$ for Ni/Al sample, 0.9 and $8.4 \mu \mathrm{m}$ for $\mathrm{Ni} / \mathrm{Cr}$ sample, 2.5 and $15.3 \mu \mathrm{m}$ for $\mathrm{Ni} / \mathrm{Cu}$ sample, 5.7 and $9.2 \mu \mathrm{m}$ for $\mathrm{Cu} / \mathrm{Fe}$ sample, and 2.8 and $16.1 \mu \mathrm{m}$ for $\mathrm{Zn} / \mathrm{Fe}$ sample. Fig. 4 shows the overall dependence of $\Delta z$ on $A_{\mathrm{c}} / A_{\mathrm{s}}$ ratio for the five samples. As can be seen, a specific level of depth resolution is obtained for each $A_{\mathrm{c}} / A_{\mathrm{s}}$ ratio range. Thus, $\Delta z$ ranges of 1-4, 4-9 and $11-16 \mu \mathrm{m}$ are obtained for $A_{\mathrm{c}} / A_{\mathrm{S}}$ ratio ranges of $0.01-0.1$, $0.1-1$ and $1-10$, respectively.

For each sample, the optimum conditions to perform the depth profiling have been considered as the $A_{\mathrm{c}} / A_{\mathrm{S}}$ ratio value, and consequently the pair of isotopes, leading to a $\Delta z$ value sufficiently low and with the lowest standard deviation (marked with an arrow in Fig. 3). These optimum pairs of isotopes are: ${ }^{62} \mathrm{Ni}-{ }^{27} \mathrm{Al}$ for $\mathrm{Ni} / \mathrm{Al}$ sample, ${ }^{62} \mathrm{Ni}-{ }^{52} \mathrm{Cr}$ for $\mathrm{Ni} / \mathrm{Cr}$ sample, ${ }^{60} \mathrm{Ni}-{ }^{63} \mathrm{Cu}$ for $\mathrm{Ni} / \mathrm{Cu}$ sample, ${ }^{65} \mathrm{Cu}-{ }^{56} \mathrm{Fe}$ for $\mathrm{Cu} / \mathrm{Fe}$ sample, and ${ }^{68} \mathrm{Zn}-{ }^{56} \mathrm{Fe}$ for $\mathrm{Zn} / \mathrm{Fe}$ sample. Although other pairs of isotopes lead to lower $\Delta z$ values, as can be seen in Fig. 3a-c and e, they are not recommended because of the high standard deviation values. The selected pairs of isotopes originate depth profile types IV and V (Table 3 and Fig. 3). These pairs of isotopes include, for the substrate element, to the isotope with the highest relative abundance (i.e., with the highest sensitivity) in all cases, and, for the coating element, to the isotope with low relative abundance (i.e., with low sensitivity) for samples giving rise to the depth profile type $\mathrm{V}(\mathrm{Ni} / \mathrm{Al}$ and $\mathrm{Ni} / \mathrm{Cr})$ and the isotope with intermediate relative abundance (i.e., with intermediate sensitivity) for samples yielding the depth profile type IV $(\mathrm{Ni} / \mathrm{Cu}$, $\mathrm{Cu} / \mathrm{Fe}$ and $\mathrm{Zn} / \mathrm{Fe}$ ). One likely explanation for these results could be related to the Gaussian profile of the laser beam and, consequently, to the cone-like shape of the craters. During in-depth analyses, a mixture of both layers (coating and substrate) occurs: the coating is still ablated although the interface coating/substrate has been reached (the wall of the crater is ablated at the same time than the bottom). Therefore a low/middle $A_{\mathrm{c}}$ value doesnot permit to detect the coating when only small amount of coating is ablated (after the interface) whereas a high $A_{\mathrm{s}}$ value permits to detect the substrate when only small amount of substrate is ablated (at the very beginning of the interface). The depth profiles of normalized signals obtained for the five samples by using the optimum pairs of isotopes are plotted in Fig. 5. The AAR, $\Delta P$ and $\Delta z$ values determined from these depth profiles are depicted in Fig. 6 . These values are the average (and the corresponding standard deviations) of 10 independent depth profiling tests for each sample.

It is known that ablation rate of metals depends on physical properties as vaporization enthalpy, thermal conductivity and reflectivity. Reflectivity of metals is not a relevant parameter in our working conditions, i.e., at a laser fluence much higher than the $F_{\text {th }}$ of the six elements studied, as abovementioned, because 

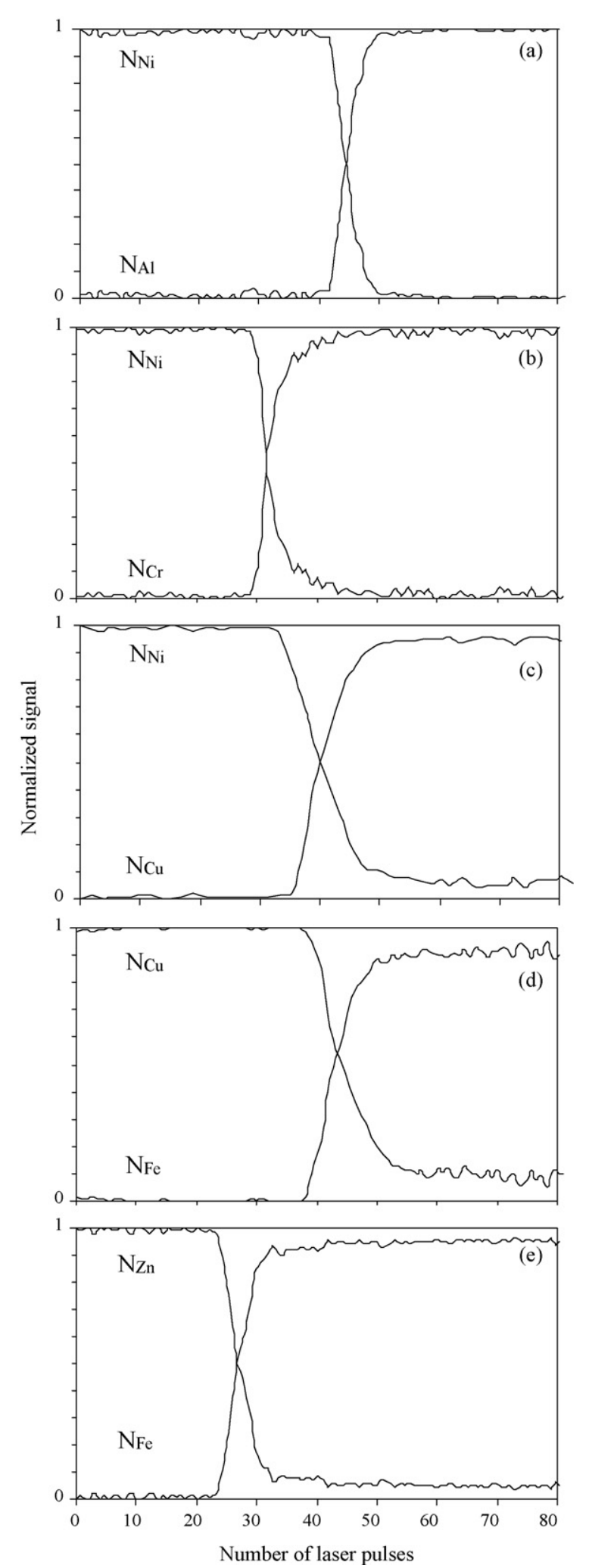

Fig. 5. Normalized in depth profiles obtained for the five samples by using the optimum pairs of isotopes: ${ }^{62} \mathrm{Ni}-{ }^{27} \mathrm{Al}$ for $\mathrm{Ni} / \mathrm{Al}$ sample (a), ${ }^{62} \mathrm{Ni}-{ }^{52} \mathrm{Cr}$ for $\mathrm{Ni} / \mathrm{Cr}$ sample (b), ${ }^{60} \mathrm{Ni}-{ }^{63} \mathrm{Cu}$ for Ni/Cu sample (c), ${ }^{65} \mathrm{Cu}-{ }^{56} \mathrm{Fe}$ for $\mathrm{Cu} / \mathrm{Fe}$ sample (d), and ${ }^{68} \mathrm{Zn}-{ }^{56} \mathrm{Fe}$ for $\mathrm{Zn} / \mathrm{Fe}$ sample (e).

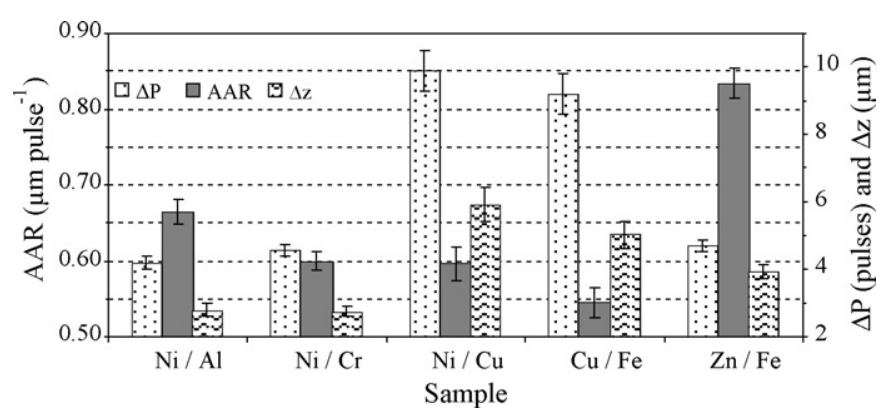

Fig. 6. AAR, $\Delta P$ and $\Delta z$ values obtained for the five samples by using the optimum pairs of isotopes indicated in Fig. 5.

in these conditions, as explained by Cabalín and Laserna [31], a high temperature plasma is formed and the laser energy can be absorbed effectively into the metal surface even if the reflectivity is high. A possible explanation to account for the comparative results obtained for AAR could be based on considering the other two properties (vaporization enthalpy and thermal conductivity) of the six elements (Table 2). It should be noted that AAR depends mainly of the coating, but also, to a lesser extent, of the substrate (see definition of AAR under Section 2 and Ref. [16]). The small differences, but significant, obtained for AAR values of the three nickel-coated samples, which must obviously be attributed to the presence of the substrate, confirm this statement.

The AAR values obtained for the five samples are in the range from 0.55 to $0.83 \mu \mathrm{m}$ pulse ${ }^{-1}$ (Fig. 6). These values show a correlation with enthalpy of vaporization (i.e., the lower the enthalpy of vaporization, the higher the AAR), excepting for samples where $\mathrm{Cu}$ is involved, for which the AAR values obtained are lower than that expected. Thus, considering the three nickel-coated samples, AAR of $\mathrm{Ni} / \mathrm{Cu}$ sample should be similar to that of $\mathrm{Ni} / \mathrm{Al}$ sample and higher than that of $\mathrm{Ni} / \mathrm{Cr}$ sample, and considering $\mathrm{Ni} / \mathrm{Cu}$ and $\mathrm{Cu} / \mathrm{Fe}$ samples, AAR of $\mathrm{Cu} / \mathrm{Fe}$ sample should be higher than that of $\mathrm{Ni} / \mathrm{Cu}$ sample. However, AAR of $\mathrm{Ni} / \mathrm{Cu}$ sample is similar to that of $\mathrm{Ni} / \mathrm{Cr}$ sample in the first case, and AAR of $\mathrm{Cu} / \mathrm{Fe}$ sample is lower than that of $\mathrm{Ni} / \mathrm{Cu}$ sample in the second one. Considering the samples with the same substrate, AAR values obtained for $\mathrm{Cu} / \mathrm{Fe}$ sample is much lower than that attained for $\mathrm{Zn} / \mathrm{Fe}$ sample, as expected, taking into account the lowest value of enthalpy of vaporization for $\mathrm{Zn}$ (Table 2).

The decrease of AAR values for samples where $\mathrm{Cu}$ is involved $(\mathrm{Ni} / \mathrm{Cu}$ and $\mathrm{Cu} / \mathrm{Fe}$ ) could be due, taking into consideration the high thermal conductivity of $\mathrm{Cu}$ (Table 2), to energy losses by heat conduction into the solid target [32]. In addition, this would also explain the high values obtained for $\Delta P$, i.e., the broadening of signals at coating/substrate interface, as can be clearly seen in Fig. $5 \mathrm{c}$ and $d$. However, the small diminution of AAR values is compensated by the high values of $\triangle P$ and, as a result, both samples present the higher $\Delta z$ values, demonstrating that $\Delta P$ is the most important factor influencing the depth resolution.

The $\Delta z$ values lie between $2.74 \mu \mathrm{m}$ for $\mathrm{Ni} / \mathrm{Cr}$ sample and $5.91 \mu \mathrm{m}$ for $\mathrm{Ni} / \mathrm{Cu}$ sample, with RSD values about $5-8 \%$. In other words, for the five samples studied, $\Delta z$ is about 4-11 times lower than the corresponding coating thickness value.

\section{Conclusions}

It has been proved that relative abundance of the isotopes used to perform the depth profiling of metal coating on metal substrates by LA-ICP-MS plays an important role on the normalized depth profile type obtained, on the one hand, and on the depth resolution and precision of results, on the other. 
A direct (non-lineal) correlation between ratio of relative abundance of the isotopes involved in the depth profiling and depth resolution has been found. A proper selection of this ratio (i.e., of the isotopes of the elements for both the coating and the substrate) is a critical factor to obtain a good depth resolution. The best depth profile types, leading to highest depth resolution and reproducibility, are attained in all cases by using the isotope of the element in the coating with a low/medium relative abundance (i.e., with a low/medium sensitivity) and the isotope of the element in the substrate with the highest relative abundance (i.e., with the highest sensitivity). In these conditions, an improvement of up to 4 times in $\Delta z$ values can be achieved.

For samples where an element with high thermal conductivity is present at either the coating or the substrate, the heat conduction into the solid target, which is the main source of energy losses during the interaction of nanosecond pulses with metals, could be the responsible for the small decrease of ablation rate and for the considerable broadening of signals at coating/substrate interface, and hence for the deterioration of depth resolution.

\section{Acknowledgements}

This work was carried out with financial support from the Spanish Ministry of Education and Science under Contracts MAT2005-00348 and MAT2009-14369-C02-01.

\section{References}

[1] S.F. Durrant, J. Anal. Atom. Spectrom. 14 (1999) 1385-1403.

[2] D. Günther, I. Horn, B. Hattendorf, Fresen. J. Anal. Chem. 368 (2000) 4-14.

[3] B. Hattendorf, C. Latkoczy, D. Günther, Anal. Chem. 75 (2003) 341A-347A.

[4] D. Günther, B. Hattendorf, Trac-Trends Anal. Chem. 24 (2005) 255-265.

[5] N.S. Mokgalaka, J.L. Gardea-Torresdey, Appl. Spectrosc. Rev. 41 (2006) 131-150.

[6] D. Bleiner, P. Lienemann, A. Ulrich, H. Vonmont, A. Wichser, J. Anal. Atom. Spectrom. 18 (2003) 1146-1153.
[7] A. Plotnikov, C. Vogt, V. Hoffmann, C. Täschner, K. Wetzig, J. Anal. Atom. Spectrom. 16 (2001) 1290-1295.

[8] A. Plotnikov, C. Vogt, K. Wetzig, J. Anal. Atom. Spectrom. 17 (2002) 1114-1120

[9] D. Bleiner, A. Plotnikov, C. Vogt, K. Wetzig, D. Günther, Fresen. J. Anal. Chem 368 (2000) 221-226.

[10] V. Kanicky, H.R. Kuhn, D. Guenther, Anal. Bioanal. Chem. 380 (2004) 218-226.

[11] J. Woodhead, J. Hergt, M. Shelley, S. Eggins, R. Kemp, Chem. Geol. 209 (2004) $121-135$.

[12] A.J.G. Mank, P.R.D. Mason, J. Anal. Atom. Spectrom. 14 (1999) 1143-1153.

[13] P.R.D. Mason, A.J.G. Mank, J. Anal. Atom. Spectrom. 16 (2001) 1381-1388.

[14] A. Hrdlicka, V. Otruba, K. Novotný, D. Günther, V. Kanický, Spectrochim. Acta B 60 (2005) 307-318.

[15] J.H. Barnes IV, G.D. Schilling, G.M. Hieftje, R.P. Sperline, M.B. Denton, C.J. Barinaga, D.W. Koppenaal, J. Am. Soc. Mass Spectrom. 15 (2004) 769-776.

[16] A.G. Coedo, T. Dorado, I. Padilla, J.C. Fariñas, J. Anal. Atom. Spectrom. 20 (2005) $612-620$.

[17] D. Bleiner, F. Belloni, D. Doria, A. Lorusso, V. Nassisi, J. Anal. Atom. Spectrom. 20 (2005) 1337-1343.

[18] J. Pisonero, I. Kroslakova, D. Günther, C. Latkoczy, Anal. Bioanal. Chem. 386 (2006) 12-20.

[19] L.I.L. Balcaen, J. Lenaerts, L. Moens, F. Vanhaecke, J. Anal. Atom. Spectrom. 20 (2005) 417-423.

[20] A.L. Hobbs, J.R. Almirall, Anal. Bioanal. Chem. 376 (2003) 1265-1271.

[21] I. Deconinck, C. Latkoczy, D. Günther, F. Govaert, F. Vanhaecke, J. Anal. Atom. Spectrom. 21 (2006) 279-287.

[22] A. Michalska, M. Wojciechowski, B. Wagner, E. Bulska, K. Maksymiuk, Anal. Chem. 78 (2006) 5584-5589.

[23] J. Pisonero, J. Koch, M. Wälle, W. Hartung, N.D. Spencer, D. Günther, Anal. Chem 79 (2007) 2325-2333.

[24] M.P. Mateo, C.C. García, R. Hergenröder, Anal. Chem. 79 (2007) 4908-4914.

[25] E.L. Gurevich, R. Hergenröder, J. Anal. Atom. Spectrom. 22 (2007) 1043-1050.

[26] R. Hergenröder, O. Samek, V. Hommes, Mass Spectrom. Rev. 25 (2006) 551-572.

[27] B. Fernández, F. Claverie, C. Pécheyran, O.F.X. Donard, Trac-Trends Anal. Chem. 26 (2007) 951-966.

[28] J. Pisonero, D. Günther, Mass Spectrom. Rev. 27 (2008) 609-623.

[29] B. Fernández, J.M. Costa, R. Pereiro, A. Sanz-Medel, Anal. Bioanal. Chem. 396 (2010) 15-29.

[30] M.P. Mateo, J.M. Vadillo, J.J. Laserna, J. Anal. Atom. Spectrom. 16 (2001) 1317-1321.

[31] L.M. Cabalín, J.J. Laserna, Spectrochim. Acta B 53 (1998) 723-730.

[32] B.N. Chichkov, C. Momma, S. Nolte, F. Alvensleben, A. Tünnermann, Appl. Phys. A 63 (1996) 109-115. 